\title{
IMPLEMENTASI MANAJEMEN KURIKULUM PESANTREN DALAM MEMBENTUK KARAKTER MANDIRI SANTRI DI PONDOK PESANTREN NURUS SIBYAN AMBAT TLANAKAN PAMEKASAN
}

\author{
Tamlihah, Abd. Mukhid, dan Hilmi Qosim Mubah ${ }^{1}$ \\ Prodi Manajemen Pendidikan Islam IAIN Madura \\ Email: tamlihah26@gmail.com,mukhid.mjk@gmail.com,dan \\ hilmiqosimmubah@iainmadura.ac.id
}

\begin{abstract}
Abstrak
Karakter mandiri merupakan hal yang harus dibentuk dan dikembangkan dalam mendidik. Penelitian ini mempelajari tentang implementasi manajemen kurikulum pesantren dalam membentuk karakter mandiri santri di Pondok Pesantren Nurus Shibyan Ambat Tlanakan Pamekasan dengan menggunakan pendekatan kualitatif dengan jenis deskriptif melalui wawancara, observasi dan dokumentasi. Hasil penelitian menunjukkan bahwa: Pertama manajemen kurikulum pesantren dalam membentuk karakter kemandirian santri yaitu menggunakan perencanaan, pengorganisasian dan pengevaluasian. Kedua pembentukan karakter kemandirian yang ada di pondok pesantren Nurus Shibyan lebih kepada pembinaan, yaitu melalui pembinaaan keteladanan, pembinaan nasehat atau dorongan. Ketiga, faktor pendukung dalam membentuk kemandirian santri yaitu kekompakan tim, keterlibatan guru dalam membentuk karakter kemandirian, dan motivasi siswa dalam pelatihan atau kegiatan. Faktor penghambatnya yaitu minimnya sarana dan prasarana yang ada di pondok pesantren, faktor pembiayaan, dan perilaku santri yang terkadang kurang disiplin.
\end{abstract}

Kata Kunci: kemandirian, manajemen kurikulum, santri

\begin{abstract}
Independent character is something that must be formed and developed in educating. This research is about the implementation of pesantren curriculum management in forming the independent character of santri in the Nurus Shibyan Ambat Tlanakan Pamekasan Islamic Boarding School by using a qualitative approach with descriptive types through interviews, observation and documentation. The results of the study show that: First the management of the pesantren curriculum in shaping the character of the santris' independence is using planning, organizing and evaluating. Secondly, the formation of the independence character in the Nurus Shibyan Islamic boarding school is more for coaching, namely through fostering exemplary, fostering advice or encouragement. Third, supporting factors in forming the independence of santries are team cohesiveness, teacher involvement in forming the character of independence, and santri motivation in training or activities. The inhibiting factors are minimal facilities and infrastructure of Islamic boarding schools, financing factors, and the behavior of santries who are sometimes undisciplined.
\end{abstract}

Keywords: independence, curriculum management, santri

${ }^{1}$ Penulis korespondensi 


\section{PENDAHULUAN}

Pesantren yang merupakan institusipendidikan berwatak khusus adalah wujud dari keunikan dan ciri khas Indonesia yang eksistensi dan peranannya telah terbukti dalam sejarah perjalanan bangsa Indonesia. Lahirnya pesantren juga sudah ada lebih dahulu sebelum lahirnya Negara Kesatuan Republik Indonesia karena pesantren didirikan oleh masyarakat dalam hal ini adalah para ulama berdasarkan kemandirian dan keikhlasan. Mulanya pesantren merupakan institusipendidikan dan penyebar luasan Islam yang berbasis masyarakat, namun searah dengan transfigurasi dinamika yang berkembang di tengah masyarakat. Pesantren pun dituntut untuk menjadi perantara transformasi sosial budaya bagi masyarakat dimana pesantren berada dalam semua bidang pendidikan dan kehidupan. ${ }^{2}$

Dalam sudut pandang pendidikan nasional, pondok pesantren adalah suatu subsistem pendidikan yang mempunyai ciri khusus. Eksistensi pondok pesantren diakui oleh Undang-undang RI Nomor 18 tahun 2019 tentang Pesantren dan Undang Undang RI No. 20 tahun 2003 tentang Sistem Pendidikan Nasional. Karakteristik kehidupan di pondok pesantren yang tidak bisa dipisahkan dari santri adalah pembelajaran hidup mandiri, sebagai orang yang berusaha untuk mempelajari ilmu keagamaan secara mendalam. Karakter mandiri itu selaras dengan tujuan pendidikan nasional. Di dalam Undang-Undang RI No. 20 tentang Sistem Pendidikan Nasional pasal 3 menetapkan fungsi pendidikan nasional yaitu fungsi pengembangan kompetensi dan fungsi pembentukan karakter dan kemajuan bangsa yang berkualitas untuk mewujudkan kehidupan bangsa yang cerdas. Selain fungsi itu, tujuan pendidikan nasional adalah membentuk insan beriman dan bertakwa kepada Allah Yang Maha Esa, berbudi luhur, sehat, berpengetahuan, cerdas, inovatif, mandiri, dan menjadi bangsa yang demokratis serta bertanggung jawab. ${ }^{3}$

Berbagai penjelasan di atas menunjukkan bahwa kemandirian adalah bagian dari capaian tujuan dalam proses pendidikan. Pendidikan nasional tidak sekedar mengembangkan kapasitas peserta didik agar menjadi insan yang beriman dan bertakwa kepada Allah swt, berbudi luhur, sehat, bepengetahuan, cerdas, inovatif, dan menjadi bangsa yang demokratis, serta tanggung jawab, juga bertujuan untuk membentuk insan mandiri.

Kurikulum pesantren memiliki ciri khas mandiri dan terbentuk atas perintah dari kiai. Dalam membina santri, kurikulum yang diberlakukan di dalamnya tidak mengikuti aturan yang baku dari pemerintah sebagaimana pendidikan formal. Pendidikan di pesantren bersudut pandang bahwa pendidikan merupakan bentuk dari ibadah terhadap sang khalik sehingga orientasi pendidikan di pesantren yang lebih mengarah pada ukhrawi menjadikan kurikulum yang dilaksanakan di pesantren berpusat pada pembelajaran untuk mempersiapkan santri sebagai orang yang tafaqquh fi al diin. Kehidupan santri di pesantren merupakan kurikulum yang tidak tertulis, mereka jauh dari orang tua, mengurus diri mereka sendiri di pondok merupakan satu keuntungan dalam membina kemandirian santri.

\footnotetext{
${ }^{2}$ Uci Sanusi, "Pendidikan Kemandirian di Pondok Pesantren Study Mengenai Realitas Kemandirian Santri di Pondok Pesantren Al Istiqlal Cianjur dan Pondok Pesantren Bahrul Ulum Tasikmalaya," Jurnal Pendidikan Agama Islam X, no. 2 (2012): 124.

${ }^{3}$ Undang-Undang Nomor 20 Tahun 2003 Tentang Sistem Pendidikan Nasional, No Title, 2003, 3.
} 
Tujuan kurikulum pondok pesantren tidak bisa lepas dari sumber utama agama Islam, yaitu Kitab Suci Al-Qur'an dan Hadis Rasulullah saw. Dari kedua sumber itu pendidikan di pesantren mempunyai orientasi membentuk santri yang berakhlak terpuji, selain itu pendidikan di pesantren mempunyai sudut pandang bahwa mendidik dan menuntut ilmu merupakan kewajiban dan bernilai ibadah. ${ }^{4}$

Sebagai institusi pendidikan Islam, pesantren memperjuangkan pelayanan sebaik mungkin kepada santrinya. Untuk melaksanakan hal tersebut, pesantren membutuhkan sokongan manajemen kurikulum yang bagus pula. Ciri sistem manajemen kurikulum yang baik adalah adanya pola pikir yang sistematis (ad ministrative thingking), pelaksanaan kegiatan yang teratur (admin istrative behavior), dan cara menyikapi tugastugas yang baik. ${ }^{5}$

Menurut pandangan umum, kurikulum sebagai agenda suatu aktivitas belajar untuk peserta didik di sekolah atau sebagai suatu instrumen terhadap tujuan yang akan dicapai. Kurikulum juga dimaknai sebagai dokumen yang berisi tentang rumusan tujuan institusi, bahan atau materi ajar, jadwal dan evaluasi. Selain itu kurikulum dipandang sebagai dokumen tertulis yang merupakan hasil konsensus bersama antara para penyusunnya dengan melibatkan pemegang kebijakan pendidikan dengan masyarakat yang mencakup lingkup tertentu, baik sekolah, kabupaten, provinsi, maupun suatu negara. Peyusunan tersebut tetap memperhatikan komponen-komponen kurikulum yang berlaku pada saat itu.

Sistem pesantren telah menjadi institusi yang lahir dari masyarakat dan diakui keberadaannya oleh masyarakat sebagai institusi pendidikan Islam. Para santri menerima pembelajaran agama maupun akhlak melalui pengajian dan pembiasaan yang mereka lakukan setiap hari di pondok pesantren serta pendidikan formal berupa madrasah yang sepenuhnya di bawah komando dan kedaulatan seorang atau beberapa orang kiai (majelis masyaikh). Kepemimpinan kiai yang berwatak kharismatik dan independen dalam semua keputusannya menjadikan pondok pesantren tidak terlalu ketat terhadap aturan pendidikan yang dikeluarkan oleh kementerian pendidikan, namun dalam pendidikan formal, para kiai tetap patuh pada aturan pemerintah. Pondok pesantren berkembang pesat di tanah air jauh sebelum Negara Indonesia merdeka bahkan sebelum nama Indonesia muncul, sehingga bisa dikatakan pendidikan pesantren merupakan pendidikan yang telah berusia tua. Saifuddin menuliskan bahwa pesantren bisa disebut sebagai institusi non-formal Islam, karena keberadaannya terdapat dalam jalur pendidikan berbasis masyarakat mempunyai program pendidikan yang disusun secara mandiri serta pada umumnya terbebas dari ketentuan formal. ${ }^{6}$

Manajemen kurikulum merupakan tata kelola kurikulum mulai dari perencanaan kurikulum, pengorganisasian, dan pengevaluasian dengan mengerahkan semua potensi lembaga untuk mencapai target pendidikan dengan baik dan maksimal. ${ }^{7}$ Sedangkan Manajemen pondok pesantren merupakan keseluruhan proses kegiatan yang mencakup

\footnotetext{
${ }^{4}$ Hilmi Qosim Mubah, Manajemen Pesantren dan Pendidikan Luar Sekolah (Pamekasan: iainmadura press, 2019$), 87$.

5 M. Sulthon Masyhud dan Moh. Khusnuridlo, Manajemen Pondok Pesantren (Jakarta: Diva Pustaka, 2003), 23.

${ }^{6}$ Ahmad Saifuddin, "Eksistensi Kurikulum Pesantren dan Kebijakan Pendidikan," Jurnal Pendidikan Agama Islam III, no. 01 (2015): 209.

${ }^{7}$ Mubah, Manajemen Pesantren dan Pendidikan Luar Sekolah, 84.
} 
perencanaan, pengorganisasian, pengarahan, dan pengendalian yang dilakukan di pondok pesantren baik dari sistem pengajaran maupun segala unsur-unsurnya dalam rangka mencapai tujuan yang telah ditetapkan. Sehingga dapat dikatakan manajemen kurikulum di pondok pesantren adalah tata kelola kurikulum yang dilaksanakan oleh pengelola pondok pesantren dalam rangaka menacapai tujuan kurikulum yang telah mereka tetapkan.

Implementasi kurikulum di pondok pesantren kemungkinan berbeda dengan institusi lain. Kekhasan yang dimiliki oleh pesantren yang tidak terikat dengan kurikulum nasional menjadikan seorang kiai bebas menentukan pilihan materi ajar yang akan diberikan kepada santrinya, tujuan pemberian pengajaran selain mentransfer ilmu juga memberikan dan meneruskan sanad keilmuan kepada para santri. Bagi seorang santri, sanad keilmuan itu adalah hal yang utama karena sanad dalam mempelajari Islam menempati kedudukan sangat penting dalam meneruskan pemahaman keilmuan. ${ }^{8}$

Dalam membina santri, pesantren memiliki waktu lebih banyak yakni seharisemalam atau selama 24 jam. Sehingga sangat mengkin membentuk karakter mandiri dalam diri santri. Karakter mandiri ini diperoleh santri melalui pembiasaan dari kegiatan-kegiatan yang ada di dalam pondok pesantren. Mulai kedisiplinan dalam tidur dan bangun tidur, belajar mandiri, mengurus diri sendiri seperti makan, mencuci pakaian, dan mengelola keuangan. Ada beberapa pengurus ketertiban dan keamanan yang akan menegur santri yang kurang disiplin dalam menjalankan kegiatan sehari-hari sehingga pembentukan karakter mandiri di pesantren sangat erat kaitannya dengan pendidikan karakter yang dilaksanakan oleh pesantren.

Deskripsi di atas merupakan hal-hal yang mendorong peneliti untuk membuat beberapa rumusan masalah yang akan menjadi fokus kajian dalam penelitian ini sehingga penelitian ini selaras dengan yang telah terencana. Fokus masalah yang telah ditetapkan oleh peneliti yaitu: pertama, deskripsi tentang implementasi manajemen kurikulum pesantren di Pondok Pesantren Nurus Shibyan Ambat Tlanakan Pamekasan. Kedua, temuan tentang program pesantren dalam membangun dan membentuk karakter mandiri santri di Pondok Pesantren Nurus Shibyan Ambat Tlanakan Pamekasan. Ketiga, temuan faktor pendukung dan penghambat dalam membentuk karakter mandiri santri di Pondok Pesantren Nurus Shibyan Ambat Tlanakan Pamekasan. Manajemen kurikulum pesantren lazim dilakukan agar program yang akan dijalankan dapat mencapai tujuan yang diinginkan, oleh karena itu peneliti tertarik untuk mengadakan studi tentang "Implementsi Manajemen Kurikulum Pesantren dalam Membentuk Karakter Mandiri Santri di Pondok Pesantren Nurus Shibyan Ambat Tlanakan Pamekasan”

\section{METODE PENELITIAN}

Penelitian ini berpendekatan kualitatif yang berjenis deskriptif karena data yang dihimpun bebentuk deskripsi, ilustrasi, dan tidak berbentuk angka. Laporan penelitian berisi berbagai kutipan data untuk memberi deskripsi dalam penyampaian laporan. Data yang didapat adalah data yang berasal dari wawancara, catatan atau memo catatan lapangan, dan foto. ${ }^{9}$

\footnotetext{
${ }^{8}$ Mubah, 46.

${ }^{9}$ Lexy J. Moleong, Metodologi Penelitian Kualitatif (Bandung: Remaja Rosdakarya, 2014), 11.
} 
Penelitian ini menggunakan pendekatan kualitatif yang bertujuan untuk menyajikan dunia sosial, dan sudut pandangnya di dalam dunia, dari sisi konsep, perilaku, pemahaman dan permasalahan tentang orang-orang yang diteliti. Harapan peneliti menggunakan pendekatan ini agar bisa lebih dekat dengan subjek penelitian dan lebih peka dalam berinteraksi, lebih mudah penyesuaian diri sehingga data yang diambil lebih mendalam dan absah.

Penelitian ini berusaha mengkaji tentang implementasi manajemen kurikulum pesantren dalam membentuk karakter mandiri santri secara mendalam. Terdapat tiga metode dalam penghimpunan data yaitu: observasi, wawancara dan dokumentasi. Penelitian ini memakai teknik observasi non partisipan sehingga peneliti hanya menjadi pengamat. Peneliti adalah orang luar dari objek penelitian, melihat dan membuat catatan lapangan dari kejauhan. Wawancara tidak terstruktur peneliti gunakan untuk memperoleh keterangan yang lebih mendalam. Sedangkan dokumentasi dimanfaatkan dalam memperkuat keabsahan data yang diperoleh dari proses wawancara dan menunjukkan bahwa peneliti benar-benar melaksanakan tugas sebagaimana mestinya. Peneliti lebih mengkhususkan kajian pada manajemen kurikulum yang ada di pondok pesantren dalam membentuk kemandirian santri, terutama program yang menunjang terhadap kemandirian santri.

\section{HASIL DAN PEMBAHASAN}

Hasil penelitian ini dapat kita diskusikan pada pembahasan di bawah ini:

\section{Manajemen kurikulum pesantren dalam membentuk karakter kemandirian santri di Pondok Pesantren Nurus Shibyan Ambat}

Manajemen Kurikulum pesantren meliputi kegiatan perencanaan (planning), organisasi (organizing), motivasi (motivating), dan pengawasan (controling). Yang mempunyai tujuan supaya semua program pembelajaran dapat dilaksanakan secara efektif dan efesien, berdaya guna dan berhasil guna di dalam dunia pendidikan. ${ }^{10}$

Dalam proses manajemen kurikulum yaitu harus menerapkan beberapa fungsi diantaranya yaitu sebagai berikut : (a) Perencanaan kurikulum. Penetapan kurikulum yang berhubungan dengan penetapan serta memprediksi tujuan. Perencanaan adalah fungsi esensial dari tata laksana pembelajaran dan harus mengarah kepada masa depan dalam pembuatan dan pengambilan keputusan tentang proses pembelajaran, harus melaksanakann beberapa teknik untuk mencapai tujuan. Guru sebagai manajer selayaknya mengelola lingkungan pendidikan sebagai lingkungan belajar dan merupakan aspek dari lingkungan pendidikan yang sanggup berorganisasi. ${ }^{11}$ (b) Pelaksanaan kurikulum. Pelaksanaan kurikulum merupakan suatu proses yang memberikan kepastian bahwa proses pembelajaran sudah mempunyai sumber daya manusia (SDM) dan sarana-prasarana yang dibutuhkan sehingga bisa menggapai tujuan yang telah dirancanakan. Fungsi pelaksanaan ini meliputi kegiatan pengorganisasian dan kepemimpinan dalam menentukan suatu kegiatan, misalnya distribusi pekerjaan ke dalam tugas yang lebih spesifik yang harus dikerjakan oleh guru dan santri dalam melaksanakan proses pembelajaran. Dari sini kita dapat mengatakan bahwa kurikulum adalah komponen yang ditawarkan oleh institusi

\footnotetext{
${ }^{10}$ Sulthon Masyhud, Manajemen Pondok Pesantren (Jakarta: Diva Pustaka, 2003), 13-14.

${ }^{11}$ Sri Minarti, Manajemen Sekolah Mengelola Lembaga Pendidikan Secara Mandiri (Yogyakarta: Ar Ruzz Media, 2017), 95.
} 
pendidikan untuk konsumennya. Semakin bagus kurikulum yang dirancang oleh pihak pesantren, maka akan tinggi pula daya pikat pesantren itu. ${ }^{12}$ (c) Evaluasi kurikulum. Evaluasi kurikulum ditujukan untuk mengontrol tujuan mana yang telah dicapai serta untuk mewujudkan tujuan pendidikan melalui kurikulum yang bersangkutan. Evaluasi juga bertujuan untuk menjamin kinerja yang dicapai sesuai dengan rencana atau tujuan yang telah ditetapkan. Dalam proses manajerial hal terakhir yang dilaksanakan dalam evaluasi yaitu membandingkan kinerja aktual dengan rencana kerja yang sudah diputuskan. Guru sebagai manajer pembelajaran seharusnya mempunyai tanggung jawab dalam memelihara lingkungan kelasnya agar menyenangkan untuk belajar dan mendidik atau membimbing mekanisme intelektual dan sosial. ${ }^{13}$

Tujuan tersebut dapat dicapai dengan penerapan manajemen berbasis pendidikan karakter di pesantren. Artinya pesantren melaksanakan pengelolaan, pemberdayaan dan pelibatan semua komponen yang ada di pesantren untuk berpartisipasi dan bertanggung jawab dalam keefektifan proses pembelajaran agar tujuan dapat tercapai dengan baik. Bukan hanya Kyai dan para ustadz sebagai pelaksana utama (aktor), namun semua pengurus yang ada di pesantren, utamanya Kyai dan Ibu Nyai yang dawuh dan nasehatnya harus diperhatikan serta perintahnya harus ditaati oleh semua komponen pesantren. Setiap pesantren mempunyai ciri khas tersendiri untuk membentuk kemandirian santri. Ini telah dibuktikan melalui kajian empiris melalui penelitian di beberapa pondok pesantren utamanya di pesantren tradisional.

Karakter mandiri dari santri dapat diperhatikan dari cara mereka melaksanakan kegiatan sehari-hari di pondok pesantren. Baik yang yang berhubungan dengan kemandirian dalam urusan makan, minum, mencuci pakaian maupun yang berhubungan dengan dalam belajar. Berbeda dengan peserta didik pada institusi pendidikan formal (dalam hal ini sekolah) yang kurang begitu tampak karakter mandiri mereka.

Pesantren adalah institusi pendidikan Islam yang memberikan pengajaran dan internalisasi ajaran agama Islam kepada para santri di dalam kehidupan. Di lingkunagn pondok-pondok sederhana mereka dituntut agar mempunyai kompetensi agama dan berbudi luhur yang kehadirannya sangat di harapkan serta bisa diterima oleh masyarakat dengan baik. ${ }^{14}$ Potret pesantren apabila ditinjau sebagai sistem pendidikan pesantren secara integral antara lain : (a) materi dan bahan pembelajaran, (b) metode pembelajaran, (c) prinsip-prinsip pendidikan, (d) sarana-prasarana pesantren, dan (d) tujuan pendidikan pesantren.

Sedangkan karakteristik yang ada dalam pondok pesantren antara lain: (a) terdapat ikatan yang erat antara santri dengan kiyainya. Kiai sangat perhatian terhadap para santrinya karena mereka berada dalam satu komplek dengan intensitas pertemuan yang tinggi, baik pada waktu belajar maupun dalam pergaulan setiap hari. Bahkan, ada beberapa santri yang diminta oleh Kiai untuk menjadi asisten (Khadam). (b) santri wajib patuh kepada Kiai. Ada anggapan bahwa ketidak patuhan merupakan

\footnotetext{
${ }^{12}$ Minarti, 97.

${ }^{13}$ Minarti, 100

${ }^{14}$ Kholis Thohir, "Kurikulum dan Sistem Pembelajaran Pondok Pesantren Salafi di Kecamatan Kresek Kabupaten Tangerang Provinsi Banten," Jurnal Analyicticaa Islamica 06, no. 01 (2017): 13-14.
} 
bentuk penentangan terhadap kiai dan itu menjadi suatu hal yang ditakuti oleh para santri sebab dari penentangan itu santri tidak mendapatkan barokah dari ilmu yang ia dapatkan, juga merupakan hal yang dilarang oleh agama dan termasuk juga durhaka kepada guru. (c) Hidup cermat, bersahaja dan ekonomis benar-benar dilaksanakan di dalam pondok pesantren, hidup berlebih-lebihan sama sekali tidak ditemui di pesantren, bahkan banyak santri yang hidupnya sangat sederhana sehingga tidak memperhatikan pemenuhan gizi. (d) Di pesantren, santri mencuci pakaian, membersihkan kamar tidur dan memasak sendiri, sehingga terbentuk watak kemandirian. (e) Karakter ta'awun (saling menolong) dan rasa persaudaraan (ukhuwah Islamiyah) sangat kental dalam pergaulan di pesantren. (f) Pesantren menerapkan disiplin, dalam melaksanakan kedisiplinan, pesantren sering memberikan sanksi-sanksi edukatif (ta'zir). (g) Pengorbanan dan tirakat dalam rangka mencapai tujuan yang mulia. Hal tersebut sebagai manifastasi dari rutunitas melaksanakan kesunnahan, zikir, iktikaf, salat tahajjud, salat duha dan berbagai macam riyadloh (amalan) serta mencontoh kiainya dalam sifat zuhud.

Penggambaran ciri khas tersebut terdapat pada pendidikan pesantren tradisional atau yang masih murni. Sedangkan untuk pendidikan pesantren modern telah melakukan perubahan secara terus menerus sehingga pesantren melakukan adopsi serta adaptasi dari berbagai sumber sebagai bagian dari dinamika dan kemajuan zaman. ${ }^{15}$

Nurcholis Majid dalam bukunya Manajemen Pondok Pesantren beliau menjelaskan bahwa ada 12 prinsip yang melekat pada pondok pesantren yaitu sebagai berikut: (a) tesentrik, (b) mengabdi dengan iklas, (c) sikap yang arif, (d) hidup sederhana, (e) kolektifitas (berakhlakul jamaah), (f) pengaturan terhadap kegiatan bersama, (g) kebebasan terpimpin, (h) kemandirian, (i) tempat mencari ilmu dan mengabdi (tholabul ilmi lil ibadah), (j) melaksanakan syariat agama. ${ }^{16}$

Pondok pesantren merupakan institusi yang bisa memberikan pengaruh signifikan dalam bidang pendidikan yang meliputi pendidikan jasmani, rohani dan daya pikir, sebab sumber norma dan nilai agama merupakan kerangka acuan dan berfikir serta sikap beragama bagi santri. Sehingga pondok pesantren di sini berfungsi sebagai perangkat transformasi kultural, pada intinya pesantren berfungsi sebagai pencetak ulama dan ahli agama. Di dalam pondok pesantren, kegiatan pembelajaran tidak hanya bertujuan untuk mentransfer ilmu pengetahuan dan kecakapan tertentu saja, akan tetapi yang paling penting ialah menanamkan nilainilai tertentu kepada santri serta membentuk nilai tersebut untuk mereka. Dalah hal ini, terdapat 3 aspek penanaman serta pembentukan nilai yang paling penting yakni aspek psikomotorik, afektif, dan kognitif yang secara stimulan dan seimbang diberikan kepada santri. ${ }^{17}$

Manajemen kurikulum Pondok Pesantren Nurus Shibyan Ambat Menggunakan beberapa fungsi yang ada dalam teori manajemen. Salah satunya yaitu perencanaan (planning), Organisasi (organizing), evaluasi (evaluating). Proses manajemen kurikulum dilakukan secara demokratis dengan cara musyawarah dengan para

\footnotetext{
${ }^{15}$ Sulthon Masyhud, Manajemen Pondok Pesantren, 93.

${ }^{16}$ Sulthon Masyhud, 91-92.

${ }^{17}$ Sanusi, "Pendidikan Kemandirian di Pondok Pesantren Study Mengenai Realitas Kemandirian Santri di Pondok Pesantren Al Istiqlal Cianjur dan Pondok Pesantren Bahrul Ulum Tasikmalaya," 124.
} 
pengurus, staf dan pihak terkait. Pengasuh pondok pesantren tidak akan mengambil keputusan dan kebijakan tanpa koordinasi dengan pengurus pondok. Pengasuh pondok pesantren selalu menekankan bahwa pengurus harus ikut serta dalam memberikan pertimbangan-pertimbangan dan saran-saran dalam rangka mengambil keputusan terkait kurikulum yang mau dilaksanakan ke depan. Masalah diidentifikasi dengan melibatkan semua elemen pondok yaitu dengan usulan serta gagasan dari pengurus, staf dan maupun dari observasi pengasuh pondok pesantren itu sendiri.

Dalam menyusun solusi alternatif terhadap permasalahan yang muncul, pengasuh pondok pesantren berusaha memberi kesempatan dan peluang kepada pengurus maupun staf untuk berperan aktif dalam memberikan sumbangan baik berupa saran, ide, dan pertimbangan-pertimbangan lainnya. Pencarian solusi seperti masalah program kegiatan santri ke depan, seperti siswa (santri) yang bermasalah dalam prestasi atau masalah lain seperti santri tidak melaksanakan kedisiplinan. Pengasuh pondok selalu berusaha dalam membangun komunikasi yang intens dengan para pengurus, staf, santri, orang tua/wali santri untuk membuka jalur komunikasi sebagai tempat tumbuhnya alternatif solusi terhadap permasalahan di pondok pesantren. Segala keputusan yang didasarkan pada otoritas mempunyai keuntungan, misalnya pengurus dan staf banyak menerima keputusan sehingga keputusan tersebut memiliki otentisitas. Kegiatan yang dilakukan dalam rangka mencapai tujuan pesantren diharapkan dapat berjalan lancar, mudah dan efisien.

\section{Program pesantren dalam membentuk kemandirian santri di Pondok Pesantren Nurus Shibyan Ambat}

Program pesantren dalam membentuk kemandirian santri lebih fokus kepada pembinaan. Pertama yaitu pembinaan melaui keteladanan, setiap pengurus atau para ustad diwajibkan memberikan tauladan atau contoh yang baik buat anak didik, kedua yaitu memberikan pembinaan berupa nasehat, artinya pengurus atau guru di sana diharuskan memberikan nasehat sebelum melakukan program dari pesantren, sebagai stimulus atau motivasi bagi santri. Ketiga yaitu melalui aturan atau perintah. Aturan atau perintah terkait program yang akan dijalankan pesantren. Terakhir yaitu pembinaan melalui sanksi atau hukuman dimana santri yang bermasalah atau santri yang tidak mengikuti program pesantren harus di berikan sanksi sesuai permasalahannya dan diatasi oleh pengurus keamanan.

\section{Faktor pendukung dan penghambat dalam membentuk kemandirian santri di Pondok Pesantren Nurus Shibyan Ambat}

Peneliti menemukan faktor pendukung dan penghambat dalam pembentukan karakter mandiri santri sebagai berikut:

a. Faktor pendukung

1) Kekompakan tim, pimpinan pesantren atau kiai sebagai Top Leader (pemimpin tertinggi) tidak hanya menjadi pemimpin yang pasif yang hanya memberikan perintah tanpa ada pemikiran sebab-akibat terlebih dahulu, tetapi mereka mempunyai keinginan dan usaha dalam mengembangkan dan membesarkan pesantrennya baik dari segi kuantitas terutama dalam segi kualitas. Dengan adanya program kemandirian santri, diharapkan alumni-alumni dari pesantren Nurus Shibyan akan mudah beradaptasi dengan masyarakat sekitar dan kuat 
dalam menghadapi rintangan kehidupan. Oleh sebab itu kompaknya elemenelemen yang terlibat dalam kegiatan ini sangat mendukung kemandirian santri.

2) Ustaz dilibatkan dalam kegiatan kemandirian santri. Guru atau disebut dengan ustaz di pondok pesantren adalah salah satu elemen pondok yang sangat berpengaruh dalam perkembangan santri. Dalam pelaksanaan program kemandirian santri, guru dan majelis guru memberikan motivasi serta dukungan sehingga pelaksanaan kemandirian santri bisa berjalan dengan baik, meskipun dalam pelaksanaannya masih terdapat kekurangan.

Peranan dan arti seorang guru di dalam pendidikan Islam itu sangat penting sebab besarnya tanggung jawab guru dalam menentukan arah pendidikan, dan Islam sangat menghargai serta menghormati seorang yang beriman dan orang yang berilmu. ${ }^{18}$

3) Motivasi santri dalam pelatihan. Di dalam pelatihan kemandirian santri, motivasi adalah faktor paling utama dalam melaksanakan pelatihan itu, jika motivasi dari santri tidak ada, maka kegiatan tidak dapat terlaksana dengan baik. Di pesantren Nurus Shibyan tersebut siswa-siswa memiliki semangat yang tinggi, hal ini bisa dilihat dari kagiatan-kegiatan yang dilaksanakan berjalan sesuai dengan yang diharapkan. Dukungan dari wali dan masyarakat sekitar, kegiatan kemandirian santri yang dilaksanakan oleh pesantren sangat didukung oleh masyarakat sekitar.

4) Peranti sederhana yang digunakan untuk memenuhi kebutuhan santri di pondok pesantren.

5) Kuatnya keinginan para santri untuk menjalani hidup mandiri dan motivasi untuk sukses.

6) Adanya santri dewasa (senior) yang membimbing santri yang lebih muda (junior) .

7) Pondok pesantren memberikan pelajaran yang mendukung santri untuk menjalani hidup mandiri.

b. Faktor penghambat

Di bawah ini adalah paparan faktor penghambat dalam menejemen kemandirian santri di pondok pesantren Nurus Shibyan, meliputi:

1) Minimnya sarana dan prasarana.

2) Faktor biaya. Biaya yang ada di pesantren sangat minim sehingga setiap kegiatan berjalan kurang baik. Banyak pengembangan kegiatan kemandirian santri yang harus dibuat, namun tidak cukupnya biaya menjadi penghambat pelaksanaan kegiatan.

3) Santri yang memiliki perilaku kurang baik seperti tidak disiplin dan sulit mematuhi peraturan.

4) terdapat santri yang tidak betah dengan keadaan lingkungan pondok pesantren, namun jumlah mereka hanya sebagian kecil saja.

18 Muchlis Solichin, Moh. Hafidz, dan Hilmi Qosim Mubah, "Kualitas Program Persiapan Guru Tugas Di Pondok Pesantren Mambaul Ulum Bata-Bata Panaan Palengaan Pamekasan," re-JIEM (Research Journal of Islamic Education Management) 2, no. 2 (2019): 2, https://doi.org/10.19105/rejiem.v2i2.2870. 
5) Sebagaimana santri yang tidak betah di pondok, santri yang tidak suka dengan peraturan pondok pesantren juga ditemukan dalam pondok dengan jumlah yang sedikit;

6) Efek negatif dari modernisasi terutama dalam perkembangan ilmu pengetahuan, teknologi, dan informasi turut mewarnai kemandirian santri di pondok pesantren sehingga santri menjadi hedonis.

7) Orang tua melaksanakan pola asuh yang manja, terutama santri baru datang di pondok pesantren. ${ }^{19}$

\section{KESIMPULAN}

Pertama manajemen kurikulum pesantren dalam membentuk karakter kemandirian santri di Pondok Pesantren Nurus Shibyan Ambat Tlanakan menggunkan beberapa fungsi manajemen antara lain yaitu sebagai berikut : perencanaan (planning), organisasi (organizing), evaluasi (evaluating). Manajemen kurikulum dalam pondok pesntren di sini pertama menggunakan perencanaan terkait program yang mau dilaksanakan kedepannya. Kedua, membentuk struktur organisasi sebagai penggerak atau pelaksana dari kurikulum tersebut. Ketiga, menggunakan evaluasi sebagai bahan penilaian terkait kurikulum yang sudah dijalankan, apakah sudah terlaksana dengan baik atau belum.

Kedua lebih ditekankan kepada pembinaan. Beberapa pembinaan yang diterapkan pondok pesantren antara lain, yang pertama menggunakan pembinaan ketauladanan. Kedua, pembinahan nasehat atau arahan. Ketiga, aturan dan yang terakhir yaitu sanksi.

Ketiga faktor pendukung dalam membentuk karakter kemandirian santri yaitu terjalinnya kerja sama yang baik antara pengasuh dan pengurus pondok pesantren, adanya kekompakan dalam staf dan pengurus pondok. Adapun faktor yang menjadi penghambat dalam pembentukan kemandirian santri antara lain: pertama, minimnya pengurus sehingga santri kurang pengawasan dari para pengurus. Kedua, Santri banyak yang berhenti sehingga sulit mencari pengganti pengurus sebagai penerus. Ketiga, Minimnya sarana dan prasarana

Berdasarkan kesimpulan hasil penelitian di atas terdapat beberapa saran yang dapat diberikan kepada beberapa pihak yaitu: 1) bagi pengasuh pondok pesantren hendaknya menambah teori manajemen pengawasan (controling) yang ada dalam fungsi manajemen sehingga setiap program yang berjalan dapat dikontrol atau dapat pengawasan langsung dalam pesantren sehingga hasilnya menjadi tambahan bahan pengevaluasian dalam pondok pesantren. 2) dalam mengembangkan sikap kemandirian siswa hendaknya guru dapat meningkatkan semua aspek sikap kemandirian, khususnya pada sikap bertanggung jawab dan mengambil keputusan. Pengembangan kemandirian pada siswa dapat dilakukan dengan mengembangkan proses belajar mengajar yang demokratis, mendorong anak untuk berpartisipasi aktif dalam pengambilan keputusan di dalam kegiatan sekolah, memberikan kebebasan kepada anak untuk mengeksplorasi lingkungan, mendorong siswa untuk rasa ingin tahu, tidak membeda-bedakan anak yang satu dengan yang lainnya, menjalin hubungan yang baik dan akrab dengan anak. 3) bagi para pengurus dan staf pesantren diharapkan lebih terbuka lagi terhadap kepala madrasah maupun kepada sesama gurupengurus dan staf saat proses musyawarah

19 Sanusi, "Pendidikan Kemandirian di Pondok Pesantren Study Mengenai Realitas Kemandirian Santri di Pondok Pesantren Al Istiqlal Cianjur dan Pondok Pesantren Bahrul Ulum Tasikmalaya,” 131. 
berlangsung, hal ini dilakukan supaya pesantren bisa mencapai visi, misi dan tujuannya lebih baik lagi.

\section{DAFTAR PUSTAKA}

A. Steenbrink, Karel. Pesantren, Madrasah, Sekolah. Jakarta : LP3ES, 1986.

Arifin, Imron. Kepemimpinan Kyai, Kasus Pondok Pesantren Tebuireng. Malang: Kalimasahada Press, 1995.

Dhofier, Zamakhsyari. Tradisi Pesantren: Studi Pandangan Hidup Kyai dan Visinya Mengenai Masa Depan Indonesia. Jakarta: LP3ES, 2011.

Efendi, Nur. Manajemen Perubahan di Pondok Pesantren. Yogyakarta: Teras 2014.

Geertz, Clofford. Abangan, Santri, Kiyai dalam Masyarakat Jawa. Jakarta: Pustaka Jaya,1981.

Haedari, Amin, dan El Saha, Ishom. Peningkatan Mutu Terpadu Pesantren dan Madrasah Diniyah. Jakarta: Diva Pustaka, 2006.

Mahfudh, M.Sahal. Pesantren Mencari Makna. Jakarta: Pustaka Ciganjur, 1999.

Mansur, Moralitas Pesantren; Meneguk Kearifan dari Telaga Kehidupan. Yogyakarta: Safiria Insania Press, 2004.

Mastuhu. Dinamika Pendidikan Pesantren; Suatu Kajian Tentang Unsur Nilai Sistem Pendidikan Pesantren. Jakarta: INIS, 1994.

Masyhud, M. Sulthon, dan Moh. Khusnuridlo. Manajemen Pondok Pesantren. Jakarta: Diva Pustaka, 2003.

Minarti, Sri. Manajemen Sekolah Mengelola Lembaga Pendidikan Secara Mandiri. Yogyakarta: Ar Ruzz Media, 2017.

Moleong, Lexy J. Metodologi Penelitian Kualitatif. Bandung: Remaja Rosdakarya, 2014.

Mubah, Hilmi Qosim. Manajemen Pesantren dan Pendidikan Luar Sekolah. Pamekasan: iainmadura press, 2019.

Oepen, Manfred dan Wolfgang Karcher. Dinamika Pesantren : Dampak Pesantren dalam Pendidikan dan Pengembangan Masyarakat. Jakarta : P3m-FNS, 1987.

Saifuddin, Ahmad. "Eksistensi Kurikulum Pesantren dan Kebijakan Pendidikan." Jurnal Pendidikan Agama Islam III, no. 01 (2015).

Sanusi, Uci. "Pendidikan Kemandirian di Pondok Pesantren Study Mengenai Realitas Kemandirian Santri di Pondok Pesantren Al Istiqlal Cianjur dan Pondok Pesantren Bahrul Ulum Tasikmalaya.” Jurnal Pendidikan Agama Islam X, no. 2 (2012).

Solichin, Muchlis, Moh. Hafidz, dan Hilmi Qosim Mubah. "Kualitas Program Persiapan Guru Tugas Di Pondok Pesantren Mambaul Ulum Bata-Bata Panaan Palengaan Pamekasan.” re-JIEM (Research Journal of Islamic Education Management) 2, no. 2 (2019): 305. https://doi.org/10.19105/re-jiem.v2i2.2870.

Sulthon Masyhud. Manajemen Pondok Pesantren. Jakarta: Diva Pustaka, 2003.

Thohir, Kholis. "Kurikulum dan Sistem Pembelajaran Pondok Pesantren Salafi di Kecamatan Kresek Kabupaten Tangerang Provinsi Banten.” Jurnal Analyicticaa Islamica 06, no. 01 (2017).

Undang-Undang Nomor 20 Tahun 2003 Tentang Sistem Pendidikan Nasional. No Title, 2003. 